\title{
富士電機 ·富士通信機材料研究所
}

大正 12 年設立後発展して來た富 士電機から昭和 10 年そつ通信機事 羓部門が富士通信機として淁立され たが，密接な関係を保ちつつ，それ ぞれ電氣機器および通信機器界の雄 として活㒛している。ちなみに富士 なる名称は相携えて本跬を興した古 河とジーメンス両刑の頭字を合せた ものとされている。

以下この 2 社の研究機関中高分子. に関係の深い部分を御紹介するので あるがそれぞれの絕緣材料に対する 要求は一口にいって强電機器関係で は耐爇性, 絕緣酎力, 機械的强度, 耐 劣化性などを特に姴求し, 通信関係 では高度の而漩性, 絕緣泩, 高周波 特性が必要とされ研究の主目標およ び設備もこの意味でそれぞれ特色が あり相補っている。

々富士電機の材料研究所は神奈川 縣川崎市にあって会邧が製造しある いは裴造しようとする强電機器, 工 業計測器などに使用する材料につい て研究している。研究分野は金属, 牛導体, 磁性材料, 絕緣材料之の他 の材料に及び, これらの基濋的研究, 実用化実驗扝よび一部材料の生座が 行われている。

電氣機器にはよく知られている高 分子材料はほとんどの種類に涉っ て,絕緣材料,構造材料として使用さ れている。したがって高分子材料の 研究には他の材料研究とともに極め て重点を貲き, この方面担当者の数 は 10 数名で, 繊維素, 㪇硬化性樹脂, 熱可塑性樹脂, 塗料, 彈性体などに ついて実䌞が行われている。この中 樹脂としては不飽和ポリエステル樹 脂, フェノール系樹脂の合成および

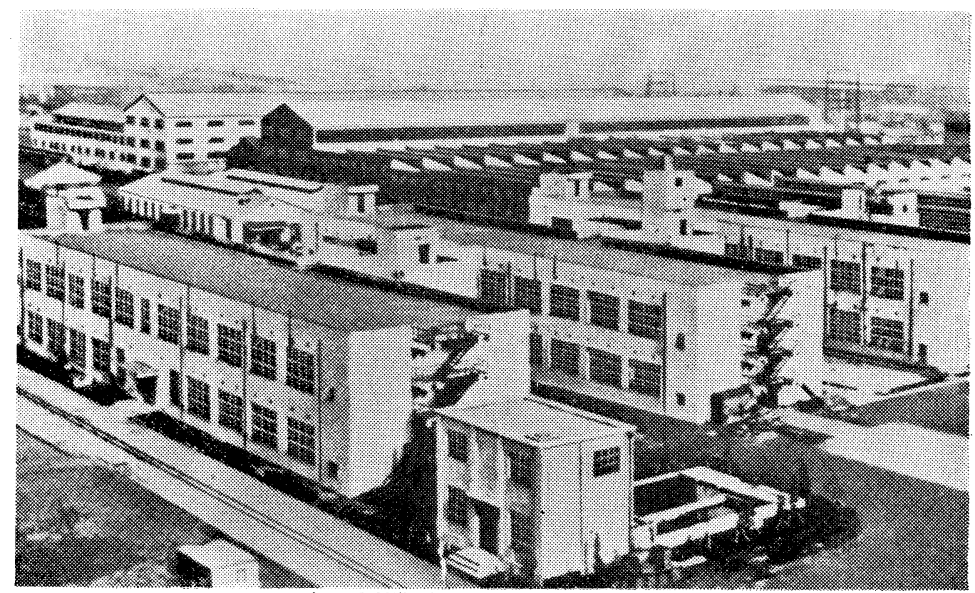

富土笔穖材料研究所（前の 2 棟）

特性の研究が特に進んでおり, 姉妹 会社である富士通信機とともに電氣 機器に邂用する上において大きな成 果を挙げている。その他繊維素類(主 として紙）に対する濕氣吸着機構と 電氣的特性との関連性, 珪素樹脂の 变態化, 熱硬化性樹脂の硬化反応の 追跡, 彈性体の特性と使用機構, 特殊 牛導休塗料の研究などのテーマもそ れぞれ電氣機器に適用する上に特殊 な高分子の研究分野として実驗が進 められている。

これらの研究実偷のために各種の スペクトル類, 可塑度計, 誘電体損 誘電率澌定器, 偏光彈泩澌定その他

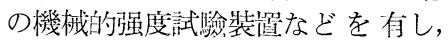
より良い材料を合理的に楜用できる よら電氣機械設計者, 工場製造技術 者らと協力している。

比較的歷史の新しい材料研究所の 高分子研究分野も高分子学会諸学兄 に対し電氣機械, たとえば発寻機,
変圧器から家庭用電氣機器などを通 じた間接の意味でなく, 高分子物理 化学として直接お役に立つような段 階になって來ていることを御報告す るとともに，諸学见の御鞭檤により 今後斯界で活躍できるよう研究員が 望んでいることをお傳えします。

富士通信機では材料研究部門は 技術部に属し, 金属, 牛導体, 管球, 嗞氣材料の研究窒とともに化学関係 としては表面処理, 分析, 材料試驗, 䑤機材料, 高分子材料, 合成などの 研究室があり, 奏踰䛇借としては阔 賣柯絕緣測定用の銳感度ガルバや誘 電特性測定用のブリッジ類や $\mathrm{Q}$ メ ーターなどの他に，プラストメータ 一その他りプラスチックス材料測定 機, Beckmann の pH メーター (G 翌), 分光光度計, 大型分光器, ポー ラログラフ，X線回折裝置などを有 し一応研究実䌞には不自由しないよ らになっており, 高周波加熱裝直や

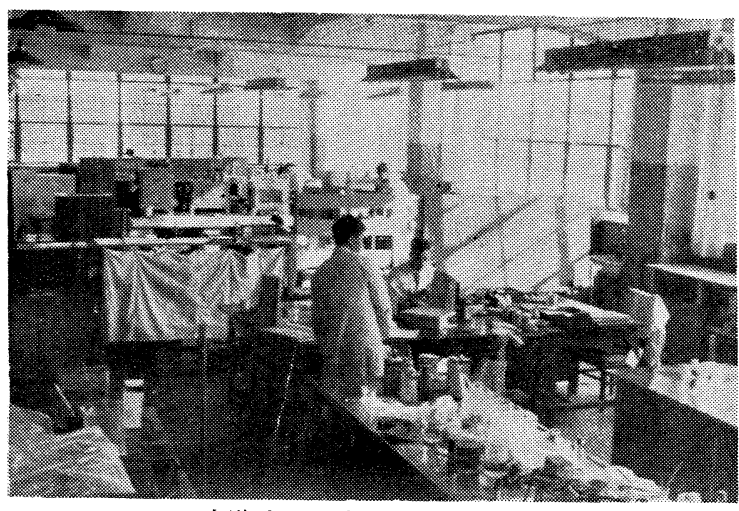

実驗室の一部（富士通信機）

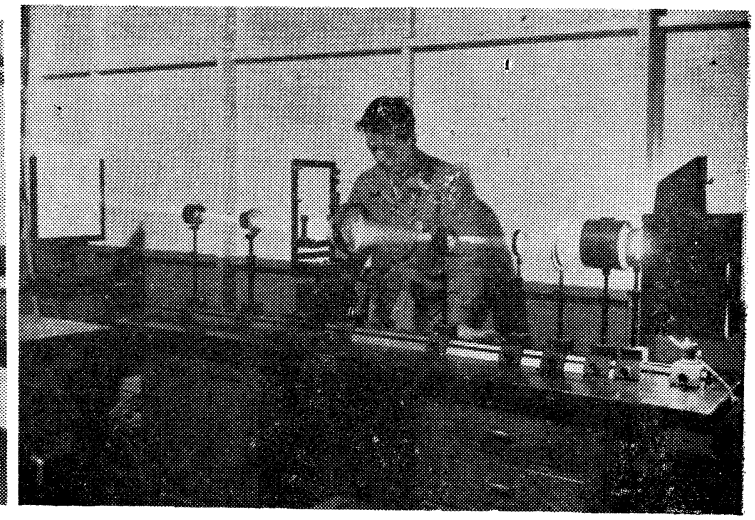

光彈性実驗裝置（富士電機） 


\section{京都大学農 学部水產学敎室}

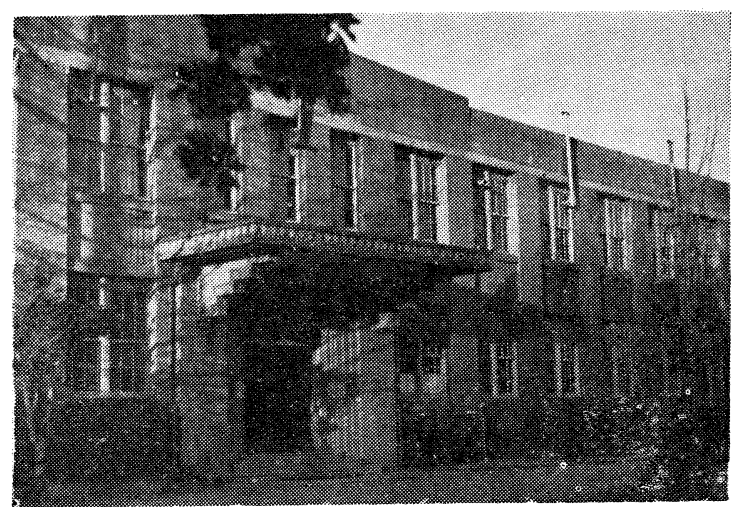

水崖学教窒の外観

「水竞学科で高分子の研究をして いる」というと妙な顏をする人が多 い。これは無理からぬことかもしれ ない。というのは水童屋郎魚屋とい うのが通念であるから。なぜわれわ れは水涯学敉室で高分子の研究をや るかについてここに大論陣を張ろう といら氣もないし，またそれをする だけの紙数も与えられていない。近 年の化学繊維の漁網界への進出がい かに大きな漁掞術の変革を生みつつ あるか, 原始的な漁其材料への合成 高分子物質の利用がいかに Promising なものであるか，著しい立遅 れにある水産化学（魚肉蛋白質の化 学) が高分子化学の研究法の導入に よっていかに促淮されるか etc. の ことを指摘すれば読者諸氏はわれわ れの目的とするところを諒とされる に違いない。われわれは水産技術者 が高分子科学の知識を身につけてそ の proper な高分子技術の世界へ どしどし進出できる日の來ることを ひたすら願っている。

本敎空注大患学部の一敎室であ るが，他敉室と異なりその誕生の日 は極めて浅く昭和 22 年にできたば かりである。しかも「海」というこ とに重点を置いて本部を遠く離れた 避地舞鶴市（引揚げでは甚だ有名で あるが) に諧惪されている。化学系 2 諆座 (清水敎授, 木俣敉授), 生物

加圧成型機などの試作裝置も設備さ れていてそれぞれ駆使されている。

表面処理関係では鋌金とともに塗 料, 塗裝の調查研究が行わ扎特殊防 濕塗料の合成研究も行われており, 無機関係にも重要な研究題目があ る。高分子関係ではポリェステル樹 脂を國內ではじめて実用化し製造し
系 1 輻座（松原呚 授), 物理采 1 临 座（川上呚授）よ り成り，いずれも 完全誹座である。

各临座とも助敉授 1名, 助手 2 名の他 に多数の新制大学 院学生を置き, 経 費難は御多聞にも れずいずこも同じ である。高分子の 研究は物理采の捧 座內の一研究窒に おいて行われてい るに過ぎないが, かかる研究は全國 他大学のどこの水產学敎室において も行われておらず, われわれの秘か に誇りとするところである。

現在は藤田助郄授を中心とし, 助 手 2 名, 大学院学生 3 名の小さい單 位で研究を進めているが，研究は昭 和 25 年にはじめたばかりで極めて 微々たる存在である。しかし, 冒頭 に述べたような目的をいだいて水座 への高分子科学の導入という希望に 燃えて仕事を進めている。目下のと ころ (1) 高分子電解質の稀薄溶液 およびゲルの研究，(2) 高分子固体 の粘彈性, とくに応力緩和の研究, (3) 非線型拡散および沈降の理論的 研究が仕事の主題となっているが, 大体物理化学的な実䜽的研究が主体 である。

藤田はここ 2〜3 年ばかり共同研 究者とともに高分子電解質稀薄溶液 の粘度について若干部細な研究を行 ったが，1954 年秋から 1955 年秋に かけてオランダ, ライデン大学の J. J. Hermans 呚授および米國ウイ スコンシン大学 J. W. Williams 敎 授の下において研究し, 最近帰朝し た。目下は Zimm 型, Gee 型, Hepp 型などの滃透圧計による高分子電解 質溶液の洷透圧測定を準備中であ る。

岸本助手は各種漁網緎維の応力緩
和について研究してきたが目下は Nylon, PVA 皮膜の応力緩和が吸 水によってどのように変るかを調べ るとともに, 大学院学生三橋ととも にジビニルベンゼンでわずかに架橋 されたポリスチレンスルフォン睃の 水中膨潤についても実羷を行ってい る。

二宮助手は Chainomatic balance による応力緩和測定裝置を用い，寒 天ゲルの粘彈性を詳しく調べたが, 目下は重合度の暴なる多くの PVAc 試料について非常に広沈なる緩和デ 一タを得ている。その結果を Ferry らの動的データと較べて種々のおも. しろい結果が出ている。このほか, 寒天ゲルの精密な彈性測定, Nylon 浮刺網の延びに関連して水中におけ る Nylon 糸の creep などの測定 も行われている。

以上のほか, 清水㸚授の研究室で は魚肉スリ身の特珙なゲル化，䐋ゲ ル化の研究がカマボコの彆造に関連 して進められているが,これも高分 子化学上甚だ興味がある。

以上の敎室紹介記を通じて「水產へ の高分子」に対するおれわれのささ やかな努力を読みとられ興味を高め られることを切に柿る次第である。

(舞鶴市長浜)

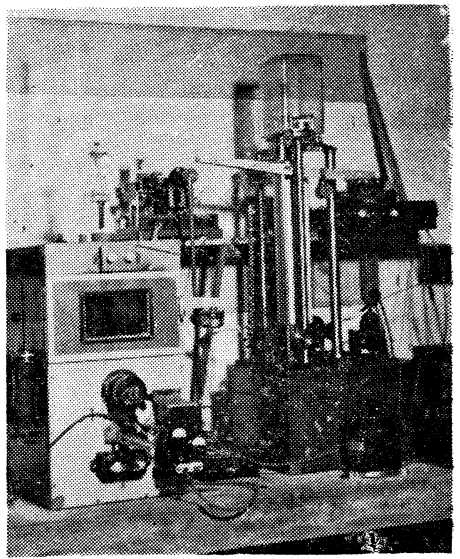

高分子固体の応力緩和測定裝徝
た経歷を生かして新しい応用, 試作 研究が行われつつあり, 同時にその 本質的研究の結果は高分子化学誌上 にぼつぼつと発表されている。その 他新しい，性能のすぐれた合成材料 に関しても, 古くから広く使われて いるフェノール樹脂積壓板の改質研 究などとともに調查がすすめられて
いる。一方,わが國では唯一つのポ リスチロールコンデンサーを含む回 路部品の性能向上の裏付けをなる材 料の試铪, 研究も大きな任務である。 このように間口は広く, しかもかな り掘り下げたデータを把握する必要 がある点は電氣材料技術者の共通 $\sigma$ ) なやみであり，また腕の振いどころ でもあろう。 


\section{学 柏 院大学理 学 部}

学丕院は 1947 年に宮內庁の手を はなれ，入学資格についての一切の 制限をとりはらって, 私立学校とし てあたらしく生まれかわった,さら に 1949 年には, 從來の初等科（小 学校) から高等科 (高等学校) まで つづく組織の上に, 理学部と交政学 部（のちに文学部と政経学部とにわ かれて発展）を有する学相院大学が 創設された。学長は安倍能成敉授で ある。

理学部は物理学科と化学科 (定員 各 30 名) および大学院修士課程 (自 然科学研究科: 物理学および化学專 攻, 定員 13 名）からなる。もとも と旧制高等科の理科の施設を母体に して発足したものではあるが，理科 教室を一旦完全に解体して全國的な 視野で少壯有雼の研究者をあつめ, 図書・実踰施設・工場の重点的充実 をはかって声新活発な敎育・研究機 関をつくりあげた。物理学敉室と化 学敉空とが完全に一体になって敎 育・研究にあたっている点, 実瞼能 力, 研究能力の養成を重視し, かつ Physical engineer や Chemical engineer としても活動できる人材 をつくるべく独自の敉育方針をとっ ている点, などは本学部の特長とみ てよいであろら。卒業生もすでに学 界で, 工業界で, 有能な活躍ぶりを みせはじめている。

以下㸚授陣の研究分野を展望しよ う。

物理関係では近藤正夫呚授は機械 的振動の測定, 微小変位の遠隔指示 などの直接に工業に寄与する閣題に

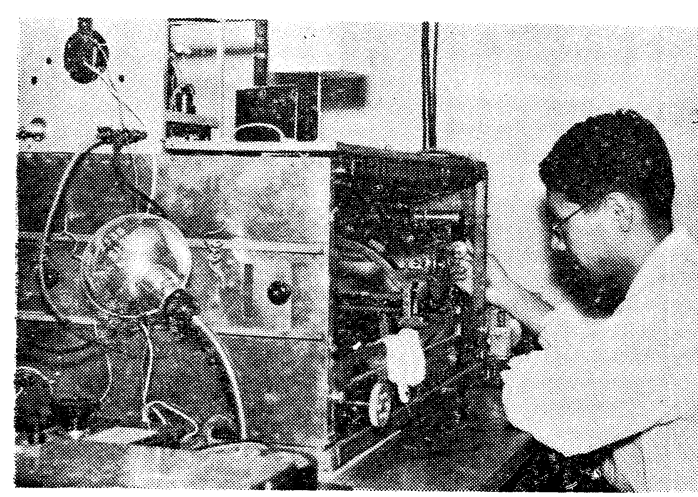

單分子膜測定裝置

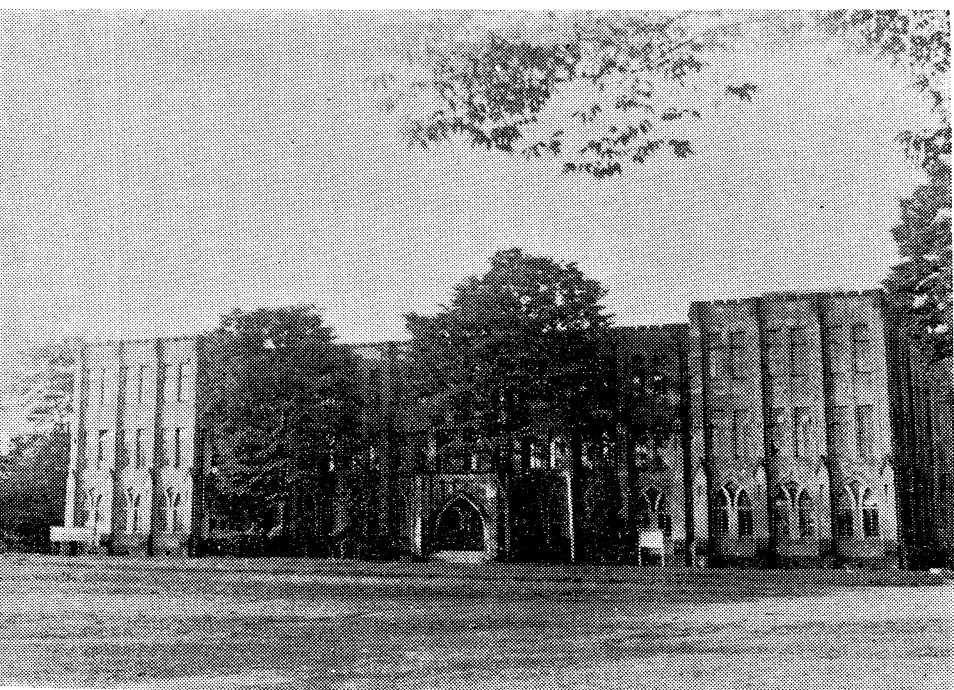

理 学 部 全 景

独自の物理的解析のメスを加えつつ あり, 大川章哉呚授は転位理論によ る結晶塑性の理論的研究で業績をあ げている。また同敎授は都立大の福 島呚授と協同でせっけん泡の模型に よる転位論の実踰をおこないつつあ る。木下是雄敉授は偏光解析法, < りかえし反射干涉法その他による固 体表面扩よび表面厥の研究，固体摩 擦の研究をすすめ，そのかたわら 最近ナイロン單纎維の力学的性質に も関心をよせている。近角聽信敎授 は强磁泩合金の磁場中冷却効果, 磁 区図形，規則格子と合金の諧性質と の関係などについて活発な実臉的研 究をす寸め, 原重義助呚授はロッシ エル塩の分域構造をテーマとする一 方, 弱電湘定器の研 究にも関心を示して いる。

理学部長佐藤孝二 㸚授は音響学專攻で あるが，その研究活 動の本拠はむしろ小 林理研と東大理工研 にある。この他数学 の滝沢周雄敉授，ま た策任敎授として岡 小天，野上茂吉郎 (原子核理論)，押田 莮雄（分子構造論） その他の榙氏がおら
れ, さらに学界の第一線で活躍して おられる多くの方が講師として協力 されている。

化学関係では, まず無機, 分析化 学方面では井上敏呚授は液体アンモ ニア中における金属錯塩の研究をつ づけ，木越邦彥敎授は放射性同位元 素による錯塩の交換反応，第 6 族元 などの題目について活発な実驗をす すめている。同敉授のもとには Libby の新銳機 Carbon-14 Age Determination Machine が谕入さ れ, 着々整備されつつある。物理化 学方面では吉田早苗敉授はX線回折

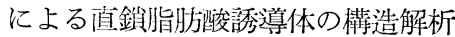
をす寸め, 江田啓一助敉授は界面化 学の㒛問題をとらえている。さらに 有機化学の領域では, 小林貞之助敉 授が蟃梅アルカロイド Calicanthin の構造決定を迫究し，また增田幸夫 講師は折れまがりの分子構造をもつ ポリアミドの合成，向山光昭啡師は 多くの有機化合物の反応機粠の研究 に活耀している。

コロイド化学の玉虫文一敉授は策 任敉授として積㥛的に協力され，ま た多くの第一線研究者が陆師として 協力されているのは物理学呚室にお けると同樣である。(東京都豊島区 目白町 1 の 1057 ・國電山手線目白駅 下車 5 分) 素のフッ化物, ${ }^{14} \mathrm{C}$ による年代測定 